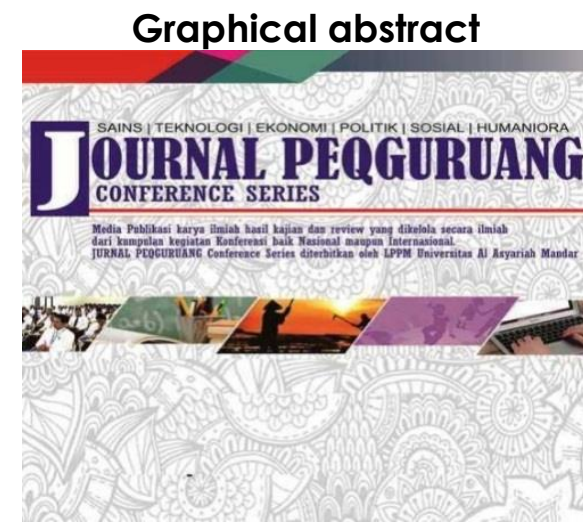

\title{
TINGKAT KEBERHASILAN PENGGUNAAN PUPUK HAYATI BIOBOOST DAN INTERVAL PEMBERIAN TERHADAP PERTUMBUHAN DAN PRODUKSI TANAMAN MENTIMUN (Cucumis sativus L. )
}

${ }^{1}$ Enice, ${ }^{2}$ Dahliah Nurdin, ${ }^{3}$ Harli A. Karim*

Program Studi Agroteknologi Fakultas Ilmu Pertanian

Universitas Al Asyariah Mandar

Harlikkarim@mail.unasman.ac.id

\section{Abstract}

This research was conducted in Timoro Village, Tabulahan Subdistrict, Mamasa Regency, which was conducted in April to July 2019. The aim was to determine the level of success in using Bioboost biofertilizers and the interval of administration of growth and production of cucumber plants. The design method used in the implementation of this study was in the form of a Randomized Group Design with a Separate Plot Design (RPT) pattern. Main plot of Bioboost (W) biological fertilizer time interval treatment includes two levels, namely: W1 = Bioboost Biofertilizer Giving biweekly W2 = Bioboost Biofertilizer giving once every three weeks Whereas Child Plot (AP) is a dose of Bioboost (F) consisting of bioboost fertilizer (F) consisting of the three levels, namely: F0 = without administration of Bioboost Biofertilizer F1 $=$ dose of Bioboost Biofertilizer 20 $\mathrm{ml}+1000 \mathrm{ml}$ of water. $\mathrm{F} 2=$ dosage of Bioboost $40 \mathrm{ml}+$ $1000 \mathrm{ml}$ water. The results showed that the interaction of the time interval of administration with the dose of bioboost biofertilizer $(\mathrm{Z} \times \mathrm{F})$ had no effect on the growth and production of cucumber plants on all parameters.

Keywords: Bioboost Biofertilizer, Giving and Cucumber Intervals

\section{Abstrak}

Penelitian ini dilaksanakan di Desa Timoro Kecamatan Tabulahan Kabupaten Mamasa yang dilaksanakan pada bulan April sampai Juli 2019. Bertujuan untuk mengetahui tingkat keberhasilan penggunaan pupuk hayati Bioboost dan interval pemberian terhadap pertumbuhan dan produksi tanaman mentimun. Metode rancangan yang digunakan pada pelaksanaan penelitian ini dalam bentuk Rancangan Acak Kelompok dengan pola Rancangan Petak Terpisah (RPT). Petak Utama perlakuan interval waktu pemberian pupuk hayati Bioboost (W) meliputi dua taraf yaitu : W1 = Pemberian Pupuk hayati Bioboost dua minggu sekali W2 = Pemberian Pupuk hayati Bioboost tiga minggu sekali Sedangkan Anak Petak (AP) adalah dosis pupuk hayati Bioboost (F) terdiri dari tiga taraf yaitu : F0 = tanpa pemberian Pupuk hayati Bioboost $\mathrm{F} 1=$ dosis Pupuk hayati Bioboost 20 $\mathrm{ml}+1000 \mathrm{ml}$ air. $\mathrm{F} 2=$ dosis Pupuk hayati Bioboost 40 $\mathrm{ml}+1000 \mathrm{ml}$ air. Hasil penelitian menunjukkan bahwa Interaksi interval waktu pemberian dengan dosis pupuk hayati bioboost ( $\mathrm{Z} \times \mathrm{x}$ ) tidak memberikan pengaruh pada pertumbuhan dan produksi tanaman mentimun pada semua parameter.

Kata Kunci : Pupuk Hayati Bioboost, Interval Pemberian dan Mentimun.

\section{Article history}

DOI: https://dx.doi.org/10.35329/ip.v2i1.760

Received : 11 Januari 2020 | Received in revised form : 27 Februari 2020 | Accepted : 21 April 2020 


\section{PENDAHULUAN}

\section{Latar Belakang}

Mentimun (Cucumis sativus L.) suku labulabuan atau Cucurbitaceaemerupakan tumbuhan yang menghasilkan buah yang dapat dimakan.Buahnya biasanya dipanen ketika belum masak benar untuk dijadikan sayuranatau penyegar, tergantung jenisnya.Mentimun dapat ditemukan di berbagai hidangan dalam makanan dan memiliki kandungan airyang cukup banyak di dalamnya sehingga berfungsi menyejukkan.Potongan buah mentimun juga digunakan untuk membantu melembabkan wajahserta dipercaya dapat menurunkan tekanan darah tinggi.Meskipun bukan merupakan tanaman asli di Indonesia, mentimun sudah sangat dikenal oleh masyarakat Indonesia.Jenis sayuran ini dengan mudah dapat ditemukan di seluruh pelosok Indonesia.

Kandungan gizi yang terdapat pada mentimun adalah protein, lemak, karbohidrat, kalsium, fospor, besi, vitamin A,C, B1, B2,B6, air, kalium, natrium. Mentimun memiliki khasiat, salah satunya adalah menurunkan tekanan darah (Rukmana, 1994) dalam (Andrie dkk, 2015)

Mentimun merupakan tumbuhan yang menghasilkan buah yang dapat dimakan baik dalam kondisi segar ataupun diolah lebih lanjut. Selain untuk bahan makanan, mentimun juga banyak digunakan sebagai bahan baku pada pada industri kecantikan. Mentimun juga memiliki banyak manfaat sebagai detoksifikasi atau peluruh racun dari dalam tubuh.Banyaknya manfaat tersebut mengakibatkan permintaan mentimunsemakin meningkat, namun tidak diimbangi dengan produksi yang baik.Untuk itu perlu dilakukan budidaya yang baik agarkebutuhan buah mentimun terpenuhi.

Hampir di setiap wilayah Indonesia mentimun menjadi alternatif komoditi yang dibudidayakan oleh petani hortikultura. Namun, hingga saat ini produktivitas yang dicapai persatuan luas lahan hanya mencapai 25 persen dari potensial produksi varietas mentimun yang beredar di Indonesia yaitu 9,98 ton/ha (Direktorat Perbenihan Hortikultura, Ditjend. Hortikultura, Kementan RI., 2012). Uji keunggulan,menunjukkan bahwaproduktivitasmentim un varietas Hibrida Manora cukup tinggi yaitu 45-55 Ton/Ha.Produksi mentimun Tahun 2016 sebesar 430.218 ton dan Tahun 2017 turun menjadi 424.917 ton (BPS, 2018).

Produksi mentimun di Indonesia masih sangat rendah padahal potensinya masih bisa ditingkatkan.Dengan kemampuan adaptasi pada berbagai iklim yang baik, tanaman ini mudah dibudidayakan.Daya serap pasar juga tidak diragukan lagi, hal ini menjadikan peluang usahauntuk budidayamentimun masih terbuka lebar.Mentimun merupakan salah satu tanaman yang syarat tumbuhnya sangat fleksibel, Karena dapat tumbuh dengan baik di dataran rendah dan dataran tinggi.Mentimun dapat tumbuh dan beradaptasi dengan hampir semua jenis tanah (Sumpena, (2001) dalam Hasyiatun Y. dkk (2015).

Pupuk kandang merupakan pupuk yang berasal dari kotoran hewan yang digunakan untuk menyediakan unsur hara bagi tanaman. Pupuk kandang berperan untuk memperbaiki sifat fisik, kimia, dan biologi tanah. Komposisi unsure hara yang terdapat pada pupuk kandang sangat tergantung jenis hewan, alas kandang dan pakan yang diberikan pada hewan tersebut. Penelitian ini bertujuan untuk mengetahui respon pemberian pupuk kandang dan media tanam yang berbeda terhadap pertumbuhan dan produksi tanaman mentimun.

Rendahnya produktivitas tanaman mentimun diIndonesia dapat disebabkan oleh beberapa faktor diantaranya adalah faktor iklim, teknik bercocok tanamseperti pengolahan tanah, pemupukan, pengairan, sertaadanya serangan hama dan penyakit (Sumpena, (2001) dalam Hasyiatun Y.dkk (2015).Produksi mentimundapat ditingkatkan dengan cara pemupukan yang tepat.Pemupukan perlu dilakukan karena kandungan haradalam tanah selalu berkurang akibat diserap olehtanaman.

Secara umum ada dua jenis pupuk, yaitu pupukorganik dan pupuk anorganik.Namun beberapa hasil penelitian membuktikan penggunaan pupuk kimia dalam jumlah yang sama dari tahun ke tahun tidak menibngkatkan produktivitas penggunaan pupuk kimia secara terus menerus dengan dosis yang meningkat setiap tahunnya justru dapat menyebabkan tanah menjadi keras dan keseimbangan unsur hara tanah terganggu. Salah satu upaya yang bisa dilakukan untuk mengatasi hal tersebut adalah dengan menerapkan system pertanian organik (Pranata, 2010 dalam Neichita, 2015).Sehingga perlu upaya mendorong para petani untuk pengembangan pupuk organik dan pupuk hayati sebagai alternatif dari masalah tersebut.

Pupuk hayati didefenisikan sebagai inokulan berbahan aktif organisme hidup yang berfungsi untuk menambat hara tertentu atau memfasilitasi tersedianya hara dalam tanah bagi tanaman (simanungkalit (2006) dalam Neichita (2015).

Salah satu pupuk hayati yang digunakan ndalam penelitian ini adalah pupuk hayati Bioboost.Komposisi Bioboost adalah sebagai berikut: 1). Azotobacter sp 2,5 x $108105 \mathrm{cf} / \mathrm{ml}, 2$.Azospirillum sp 3 x 107105 cf/ml3. Bacillus sp 3,5 x 107105 cf/ml4. Pseudomonas sp 7 x $105104 \mathrm{cf} / \mathrm{ml}$. Cytophaga sp 1,5 x $104103 \mathrm{cf} / \mathrm{ml}$.

Djiwosaputro(1990) dalam Hidayat, dkk., (2013),bahwa tanaman akan tumbuh dengan baik apabila unsur hara yang diberikan berada dalam jumlah yangseimbang dan sesuai dengan kebutuhan tanaman.Soetejo dan Kartasapoetra, (1991)dalam Silvester Muga Sada (2018) menyatakan bahwa frekuensi pemberian pupuk berpengaruh terhadap unsur hara dalam tanah dan pemanfaatan unsur hara pada tanaman. Waktu aplikasi pupuk yang tepatakan meningkatkan pertumbuhan serta produksi tanaman. Tetapi pemberian pupuk dengan interval waktu yang terlalu sering berdampak pada pemborosan pupuk serta berdampak negatif pada tanaman berupa kelayuan. Sebaliknya, bila intervalpemupukan terlalu jarang menyebabkan kebutuhanhara tanaman kurang terpenuhi.

Berdasarkan hal tersebut diatas, maka perlu diadakan penelitian tentang "Tingkat keberhasilan penggunaan pupuk hayatiBioboostdan interval 
pemberian terhadap pertumbuhan dan produksi tanaman mentimun (Cucumis sativus L.).

\section{Tujuan dan Kegunaan}

Penelitian ini bertujuan untuk mengetahui tingkat keberhasilan penggunaan pupuk hayati Bioboostdan interval pemberian terhadap pertumbuhan dan produksi tanaman mentimun.

Kegunaan penelitian ini diharapkan menjadi bahan informasi dalam upaya pemanfaatan dan optimalisasi pemberianpupuk hayatiterhadap pertumbuhan dan produksi tanaman mentimunserta sebagai bahan pembanding pada penelitian selanjutnya.

\section{BAHAN DAN METODE}

\section{Tempat dan Waktu}

Penelitiuan inidilaksanakan diDesa Timoro Kecamatan TabulahanKabupaten Mamasa, yang dilaksanakan selama tiga bulan berlangsung pada bulan April sampai dengan Juli 2019.

\section{Bahan dan Alat}

Bahan yang digunakan dalam penelitian ini adalah benih tanaman mentimun,pupuk hayati Bioboost.

Adapun alat yangdigunakan meliputi ember, meter, cangkul, sekop, parang, timbangan, pisau, lanjaran, tali, alat dokumentasi dan alat tulis menulis.

\section{Metode Pelaksanaan}

Metode rancangan yang digunakan padapelaksanaan penelitian ini dalam bentuk Rancangan Acak Kelompok dengan pola Rancangan Petak Terpisah (RPT).Petak Utama (PU) adalah perlakuan interval waktu pemberian pupuk hayati Bioboost (W) meliputidua taraf yaitu :

W1=Pemberian Pupuk hayati Bioboost dua minggu sekali

W2=Pemberian Pupuk hayati Bioboost tiga minggu sekali

Sedangkan Anak Petak (AP) adalah dosis pupuk hayati Bioboost (F) terdiri dari tiga taraf yaitu :

F0=tanpa pemberian Pupuk hayati Bioboost

$\mathrm{F} 1=$ dosis Pupuk hayati Bioboost $20 \mathrm{ml}+1000$ $\mathrm{ml}$ air

$\mathrm{F} 2=$ dosis Pupuk hayati Bioboost $40 \mathrm{ml}+1000$ $\mathrm{ml}$ air

Pelaksanaan penelitian dilakukan dengan 6 (enam) kombinasi perlakuan sebagai berikut :

F0W1 F1W1 F2W1

F0W2 F1W2 F2W2

Kombinasi setiap perlakuan masing-masing diulang sebanyak 3 (tiga) ulangan sehingga terdapat 18 unit penelitian, dimana setiap unit terdapat empat tanaman sehingga jumlah tanaman yang digunakan sebanyak 72 tanamanmentimun.

\section{HASIL DAN PEMBAHASAN}

\section{Hasil}

\section{Umur Berkecambah}

Data pengamatan umur berkecambah dan sidik ragamnya disajikan pada Tabel Lampiran 1a dan Tabel Lampiran 1b. Sidik ragam menunjukkan interval pemberian (W) tidak berpengaruh namun penggunaan dosis pupuk hayati Bioboost (F) berpengaruh nyata, sedangkan interaksi interval pemberian dengan penggunaan dosis pupuk Hayati Bioboost (W x F) tidak berpengaruh nyata pada umur berkecambah tanaman mentimun.

\begin{tabular}{|c|c|c|c|c|}
\hline \multirow{2}{*}{$\begin{array}{c}\text { Interval } \\
\text { Pemberian (W) }\end{array}$} & \multicolumn{3}{|c|}{ Dosis Pupuk Hayati Bioboost (F) } & \multirow{2}{*}{$\begin{array}{l}\text { Rata- } \\
\text { rata }\end{array}$} \\
\hline & $\begin{array}{c}\mathrm{F} 0 \\
(0 \mathrm{ml} / \mathrm{l} \text { air })\end{array}$ & $\begin{array}{c}\mathrm{F} 1 \\
(20 \mathrm{ml} / \mathrm{l} \text { air }) \\
\end{array}$ & $\begin{array}{c}\mathrm{F} 2 \\
(40 \mathrm{ml} / \mathrm{l} \text { air })\end{array}$ & \\
\hline $\begin{array}{c}\text { W1 } \\
(2 \text { minggu })\end{array}$ & 5,00 & 4,00 & 4,67 & 4,56 \\
\hline $\begin{array}{c}\text { W2 } \\
\text { (2 minggu) }\end{array}$ & 5,33 & 4,00 & 4,00 & 4,44 \\
\hline Rata-rata & $5,16^{a}$ & 4,00 b & 4,33 b & \\
\hline NP.BNT a 0,05 & 1,13 & & & \\
\hline
\end{tabular}

Analisis Beda Nyata Terkecil Taraf a 0,05 pada Tabel 1 menunjukkan penggunaan dosis pupuk hayati bioboost dosis $20 \mathrm{ml}+1000 \mathrm{ml}$ air (F1) berpengaruh lebih baik dan berbeda nyata dibandingkan dengan tanpa penggunaan pupuk hayati bioboost (F0) namun penggunaan dosis pupuk hayati bioboost dosis $20 \mathrm{ml}+1000 \mathrm{ml}$ air (F1) tidak berbeda dengan penggunaan dosis pupuk hayati bioboost dosis $40 \mathrm{ml}+1000 \mathrm{ml}$ air (F2) pada umur berkecambah tanaman mentimun.

Jumlah Daun

Data pengamatan jumlah daun dan sidik ragamnya disajikan pada Tabel Lampiran 2a dan Tabel Lampiran 2b. Sidik ragam menunjukkan interval pemberian pupuk hayatibioboost (W) tidak berpengaruh sedangkan penggunaan dosis pupuk hayati bioboost (F) berpengaruh nyata namun interaksi interval pemberian dengan penggunaan dosis pupuk hayati bioboost (W x F) tidak berpengaruh nyata pada jumlah daun tanaman mentimun.

\begin{tabular}{|c|c|c|c|c|}
\hline \multirow{2}{*}{$\begin{array}{c}\text { Interval } \\
\text { Pemberian }(W)\end{array}$} & \multicolumn{3}{|c|}{ Dosis Pupuk hayati Bioboost (F) } & \multirow[b]{2}{*}{ Rata-rata } \\
\hline & $\begin{array}{c}\mathrm{F} 0 \\
(0 \mathrm{~m} / / \mathrm{l} \text { air })\end{array}$ & $\begin{array}{c}\mathrm{F} 1 \\
(20 \mathrm{~m} / / \mathrm{l} \text { air })\end{array}$ & $\begin{array}{c}\mathrm{F} 2 \\
(40 \mathrm{~m} / / \mathrm{l} \text { air })\end{array}$ & \\
\hline $\begin{array}{c}\text { W1 } \\
\text { (2 minggu) }\end{array}$ & 14,67 & 14,67 & 16,33 & 15,22 \\
\hline $\begin{array}{c}\text { W2 } \\
\text { (2 minggu) }\end{array}$ & 13,33 & 15,00 & 16,67 & 15,00 \\
\hline Rata-rata & $14,00^{a}$ & $14,84 \mathrm{~s}$ & $16,50 \mathrm{sb}$ & \\
\hline NP.BNT a 0,05 & 1,75 & & & \\
\hline
\end{tabular}

Analisis Beda Nyata Terkecil Taraf a 0,05 pada Tabel 2 menunjukkan penggunaan dosis pupuk hayati bioboost dosis $40 \mathrm{ml}+1000 \mathrm{ml}$ air (F2) berpengaruh lebih baik dan berbeda nyata dibandingkan dengan tanpa penggunaan pupuk hayati bioboost (F0) namun penggunaan dosis pupuk hayati bioboost dosis $40 \mathrm{ml}+1000 \mathrm{ml}$ air (F2) tidak berbeda dengan penggunaan dosis pupuk hayati bioboost dosis $20 \mathrm{ml}+1000 \mathrm{ml}$ air (F1) pada jumlah tanaman mentimun

\section{Umur Berbunga}

Data pengamatan umur berbunga dan sidik ragamnya disajikan pada Tabel Lampiran 3a dan Tabel Lampiran 3b. Sidik ragam menunjukkan 
interval pemberian (W) tidak berpengaruh namun penggunaan dosis pupuk hayati bioboost (F) berpengaruh nyata, sedangkan interaksi interval pemberian pupukhayati bioboost dengan penggunaan dosis pupuk hayati bioboost (W x F) tidak berpengaruh nyata pada umur berbunga tanaman mentimun.

Tabel ß. Rata-Rata Umur Berbunga Pada Interval Pemberian dengan Penggunaan Dosis Pupuk hayati Bioboost Terhadap Pertumbuhan dan Produksi Tanaman Mentimun.

\begin{tabular}{|c|c|c|c|c|}
\hline \multirow{2}{*}{$\begin{array}{c}\text { Interval } \\
\text { Pemberian }(W)\end{array}$} & \multicolumn{3}{|c|}{ Dosis Pupuk hayati Bioboost (F) } & \multirow[b]{2}{*}{ Rata-rata } \\
\hline & $\begin{array}{c}\mathrm{F} 0 \\
(0 \mathrm{ml} / \mathrm{l} \text { air })\end{array}$ & $\begin{array}{c}\mathrm{F} 1 \\
(20 \mathrm{ml} / \mathrm{l} \text { air })\end{array}$ & $\begin{array}{c}\mathrm{F} 2 \\
(40 \mathrm{ml} / \mathrm{l} \text { air })\end{array}$ & \\
\hline $\begin{array}{c}\text { W1 } \\
(2 \text { minggu) }\end{array}$ & 23,33 & 21,67 & 22,33 & 22,44 \\
\hline $\begin{array}{c}\text { W2 } \\
\text { (2 minggu) }\end{array}$ & 23,33 & 21,67 & 21,33 & 22,11 \\
\hline Rata-rata & $23,33^{a}$ & 21,67 b & 21,83 bc & \\
\hline NP.BNT a 0,05 & 0,99 & & & \\
\hline
\end{tabular}

Keterangan: Angka-angka yang diikuti oleh huruf yang berbeda berart berbeda nyata pada Uji Beda Nyata Terkecil taraf a 0,05.

Analisis Beda Nyata Terkecil Taraf a 0,05 pada Tabel 3 menunjukkan penggunaan dosis pupuk hayati bioboost dosis $40 \mathrm{ml}+1000 \mathrm{ml}$ air (F2) berpengaruh lebih baik dan berbeda nyata dibandingkan dengan tanpa penggunaan pupuk hayati bioboost (F0) namun penggunaan dosis pupuk hayati bioboost dosis $40 \mathrm{ml}+1000 \mathrm{ml}$ air (F2) tidak berbeda dengan penggunaan dosis pupuk hayati bioboost dosis $20 \mathrm{ml}+1000 \mathrm{ml}$ air (F1) pada umur berbunga tanaman mentimun.

\section{Jumlah Bunga}

Data pengamatan jumlah bunga dan sidik ragamnya disajikan pada Tabel Lampiran 4a dan Tabel Lampiran 4b. Sidik ragam menunjukkan interval pemberian (W) tidak berpengaruh namun penggunaan dosis pupuk hayati bioboost (F) berpengaruh nyata, sedangkan interaksi interval pemberian dengan penggunaan dosis pupuk hayati bioboost (W x F) tidak berpengaruh nyata pada jumlah bunga tanaman mentimun.

Tabel 4. Rata-Rata Jumlah Bunga Pada Interval Pemberian dengan Penggunaan Dosis Pupuk Hayati Bioboost Terhadap Pertumbuhan dan Produksi Tanaman Mentimun.

\begin{tabular}{|c|c|c|c|c|}
\hline \multirow{2}{*}{$\begin{array}{c}\text { Interval } \\
\text { Pemberian }(W)\end{array}$} & \multicolumn{3}{|c|}{ Dosis Pupuk Hayati Bioboost (F) } & \multirow[b]{2}{*}{ Rata-rata } \\
\hline & $\begin{array}{c}\mathrm{F} 0 \\
(0 \mathrm{ml} / \mathrm{l} \text { air })\end{array}$ & $\begin{array}{c}\mathrm{F} 1 \\
(20 \mathrm{~m} / \mathrm{l} \text { air })\end{array}$ & $\begin{array}{c}\mathrm{F} 2 \\
(40 \mathrm{ml} / \mathrm{l} \text { air })\end{array}$ & \\
\hline $\begin{array}{c}\text { W1 } \\
(2 \text { minggu) }\end{array}$ & 8,00 & 9,67 & 9,33 & 9,00 \\
\hline $\begin{array}{c}\text { W2 } \\
\text { (2 minggu) }\end{array}$ & 7,00 & 10,67 & 10,00 & 9,22 \\
\hline Rata-rata & $7,50^{\text {a }}$ & 10,17 b & 9,67 bc & \\
\hline NP.BNT a 0,05 & 1,51 & & & \\
\hline
\end{tabular}

Analisis Beda Nyata Terkecil Taraf a 0,05 pada Tabel 4 menunjukkan penggunaan dosis pupuk hayati bioboost dosis $40 \mathrm{ml}+1000 \mathrm{ml}$ air (F2) berpengaruh lebih baik dan berbeda nyata dibandingkan dengan tanpa penggunaan pupuk hayati bioboost (F0) namun penggunaan dosis pupuk hayati bioboost dosis $40 \mathrm{ml}+1000 \mathrm{ml}$ air (F2) tidak berbeda dengan penggunaan dosis pupuk hayati bioboost dosis $20 \mathrm{ml}+1000 \mathrm{ml}$ air (F1) pada jumlah bunga tanaman mentimun

Jumlah Buah
Data pengamatan jumlah buah dan sidik ragamnya disajikan pada Tabel Lampiran 5a dan Tabel Lampiran 5b. Sidik ragam menunjukkan interval pemberian (W) tidak berpengaruh namun penggunaan dosis pupuk hayati bioboost (F) berpengaruh nyata, sedangkan interaksi interval pemberian dengan penggunaan dosis pupuk hayati bioboost (W x F) tidak berpengaruh nyata pada jumlah buah tanaman mentimun. Tabel 5. Rata-Rata Jumlah Buah Pada Interval Pemberian dengan
Penggunaan Dosis Pupuk Hayati Bioboost Terhadap
Pertumbuhan dan Produksi Tanaman Mentimun.

\begin{tabular}{|c|c|c|c|c|}
\hline \multirow{2}{*}{$\begin{array}{c}\text { Interval } \\
\text { Pemberian }(\mathrm{W})\end{array}$} & \multicolumn{3}{|c|}{ Dosis Pupuk hayati Bioboost (F) } & \multirow[b]{2}{*}{ Rata-rata } \\
\hline & $\begin{array}{c}\mathrm{F} 0 \\
(0 \mathrm{ml} / \mathrm{l} \text { air })\end{array}$ & $\begin{array}{c}\mathrm{F} 1 \\
(20 \mathrm{ml} / \mathrm{l} \text { air })\end{array}$ & $\begin{array}{c}\mathrm{F} 2 \\
(40 \mathrm{~m} / \mathrm{l} \text { air })\end{array}$ & \\
\hline $\begin{array}{c}\mathrm{W} 1 \\
(2 \text { minggu) }\end{array}$ & 5,33 & 6,33 & 6,67 & 6,11 \\
\hline $\begin{array}{c}\text { W2 } \\
\text { (2 minggu) }\end{array}$ & 4,67 & 6,33 & 6,33 & 5,78 \\
\hline Rata-rata & $5,00^{a}$ & 6,33 b & 6,50 bc & \\
\hline NP.BNT a 0,05 & 0,99 & & & \\
\hline$n: \operatorname{Ar}$ & $\begin{array}{l}\text { angka y } \\
\text { la nyata }\end{array}$ & $\begin{array}{l}\text { diikuti oleh } \\
\text { a Uji Beda }\end{array}$ & $\begin{array}{l}\text { huruf yang } \\
\text { yata Terkecil }\end{array}$ & $\begin{array}{l}\text { erbeda b } \\
\text { araf } a 0,0\end{array}$ \\
\hline
\end{tabular}

Analisis Beda Nyata Terkecil Taraf a 0,05 pada Tabel 5 menunjukkan penggunaan dosis pupuk hayati bioboost dosis $40 \mathrm{ml}+1000 \mathrm{ml}$ air (F2) berpengaruh lebih baik dan berbeda nyata dibandingkan dengan tanpa penggunaan pupuk hayati bioboost (F0) namun penggunaan dosis pupuk hayati bioboost dosis $40 \mathrm{ml}+1000 \mathrm{ml}$ air (F2) tidak berbeda dengan penggunaan dosis pupuk hayati bioboost dosis $20 \mathrm{ml}+1000 \mathrm{ml}$ air (F1) pada jumlah buah tanaman mentimun.

\section{Panjang Buah}

Data pengamatan panjang buah dan sidik ragamnya disajikan pada Tabel Lampiran 6a dan Tabel Lampiran 6b. Sidik ragam menunjukkan interval pemberian (W) tidak berpengaruh namun penggunaan dosis pupuk hayati bioboost (F) berpengaruh nyata, sedangkan interaksi interval pemberian dengan penggunaan dosis pupuk hayati bioboost (W $\mathrm{x}$ F) tidak berpengaruh nyata pada panjang buah tanaman mentimun. Tabel 6. Rata-Rata Panjang Buah Pada Interval Pemberian dengan
Penggunaan Dosis Pupuk hayati Bioboost Terhadap Pertumbuhan dan Produksi Tanaman Mentimun.

\begin{tabular}{|c|c|c|c|c|}
\hline \multirow{2}{*}{$\begin{array}{c}\text { Interval } \\
\text { Pemberian }(W)\end{array}$} & \multicolumn{3}{|c|}{ Dosis Pupuk hayati Bioboost (F) } & \multirow[b]{2}{*}{ Rata-rata } \\
\hline & $\begin{array}{c}\mathrm{F} 0 \\
(0 \mathrm{ml} / \mathrm{l} \text { air })\end{array}$ & $\begin{array}{c}\mathrm{F} 1 \\
(20 \mathrm{ml} / \mathrm{l} \text { air })\end{array}$ & $\begin{array}{c}\mathrm{F} 2 \\
(40 \mathrm{ml} / \mathrm{l} \text { air })\end{array}$ & \\
\hline $\begin{array}{c}\text { W1 } \\
\text { (2 minggu) }\end{array}$ & 20,07 & 23,27 & 22,73 & 22,02 \\
\hline $\begin{array}{c}\text { W2 } \\
\text { (2 minggu) }\end{array}$ & 20,73 & 22,77 & 24,00 & 22,50 \\
\hline Rata-rata & $20,40^{a}$ & 23,02 b & 23,36 bc & \\
\hline NP.BNT a 0,05 & 2,70 & & & \\
\hline an : $A$ & $\begin{array}{l}\text { a-angka } \\
\text { da nyat }\end{array}$ & $\begin{array}{l}\text { dilikuti } \\
\text { a Uji Bed }\end{array}$ & $\begin{array}{l}\text { huruf yal } \\
\text { yata Terke }\end{array}$ & $\begin{array}{l}\text { rrbeda be } \\
\text { Iraf } a 0,0\end{array}$ \\
\hline
\end{tabular}

Analisis Beda Nyata Terkecil Taraf a 0,05 pada Tabel 6 menunjukkan penggunaan dosis pupuk hayati bioboost dosis $40 \mathrm{ml}+1000 \mathrm{ml}$ air (F2) berpengaruh lebih baik dan berbeda nyata dibandingkan dengan tanpa penggunaan pupuk hayati bioboost (F0) namun penggunaan dosis pupuk hayati bioboost dosis $40 \mathrm{ml}+1000 \mathrm{ml}$ air (F2) tidak berbeda dengan penggunaan dosis pupuk hayati bioboost dosis 
$20 \mathrm{ml}+1000 \mathrm{ml}$ air (F1) pada panjang buah tanaman mentimun.

\section{Berat Buah}

Data pengamatan berat buah dan sidik ragamnya disajikan pada Tabel Lampiran $7 \mathrm{a}$ dan Tabel Lampiran 7b. Sidik ragam menunjukkan interval pemberian (W) tidak berpengaruh namun penggunaan dosis pupuk hayati bioboost (F) berpengaruh sangat nyata, sedangkan interaksi interval pemberian dengan penggunaan dosis pupuk hayati bioboost $(\mathrm{W} \times \mathrm{F})$ tidak berpengaruh nyata pada berat buah tanaman mentimun.

\begin{tabular}{|c|c|c|c|c|}
\hline \multirow{2}{*}{$\begin{array}{c}\text { Interval } \\
\text { Pemberian }(W)\end{array}$} & \multicolumn{3}{|c|}{ Dosis Pupuk hayati Bioboost (F) } & \multirow[b]{2}{*}{ Rata-rata } \\
\hline & $\begin{array}{c}\mathrm{F} 0 \\
(0 \mathrm{ml} / \mathrm{l} \text { air })\end{array}$ & $\begin{array}{c}\mathrm{F} 1 \\
(20 \mathrm{ml} / \mathrm{l} \text { air })\end{array}$ & $\begin{array}{c}\mathrm{F} 2 \\
(40 \mathrm{ml} / \mathrm{l} \text { air })\end{array}$ & \\
\hline $\begin{array}{c}\text { W1 } \\
\text { (2 minggu) }\end{array}$ & 332,33 & 387,33 & 404,00 & 374,55 \\
\hline $\begin{array}{c}\text { W2 } \\
\text { (2 minggu) }\end{array}$ & 347,00 & 413,33 & 412,00 & 390,78 \\
\hline Rata-rata & $339,66^{\text {a }}$ & 400,33 b & 408,00 bc & \\
\hline NP.BNT a 0,01 & 73,29 & & & \\
\hline \multicolumn{5}{|c|}{$\begin{array}{l}\text { Keterangan : Angka-angka yang diikuti oleh huruf yang berbeda berar } \\
\text { berbeda sangat nyata pada Uji Beda Nyata Terkecil taraf } \\
0,01 \text {. }\end{array}$} \\
\hline
\end{tabular}

Analisis Beda Nyata Terkecil Taraf a 0,01 pada Tabel 7 menunjukkan penggunaan dosis pupuk hayati bioboost dosis $40 \mathrm{ml}+1000 \mathrm{ml}$ air (F2) berpengaruh lebih baik dan berbeda nyata dibandingkan dengan tanpa penggunaan pupuk hayati bioboost (F0) namun penggunaan dosis pupuk hayati bioboost dosis $40 \mathrm{ml}+1000 \mathrm{ml}$ air (F2) tidak berbeda dengan penggunaan dosis pupuk hayati bioboost dosis $20 \mathrm{ml}+1000 \mathrm{ml}$ air (F1) pada berat buah tanaman mentimun.

\section{Pembahasan \\ Umur Berkecambah}

Penggunaan pupuk hayati bioboost dengan dosis yang berbeda pada tanaman buncis memberikan pengaruh baik (Tabel Lampiran 1b). Pupuk hayati bioboost merupakan pupuk yang bersumber dari bahan organik yang dalam komposisinya ditujukan untuk perbaikan pertumbuhan dan meningkatkan produksi.

Hasil penelitian pemberian pupuk hayati bioboost $20 \mathrm{ml} /$ liter air (Tabel 1) berpengaruh baik pada umur berkecambah tanaman mentimun, hal ini sangat dimungkinkan karena pupuk hayatibioboost berbentuk cair sehingga mudah diserap oleh tanah, dan ketika benih mentimun ditanam pada media tanah yang telah diberi pupuk hayati bioboost maka tanah dalam kondisi yang siap karena pupuk hayatibioboost mengandung bakteri unggul sehingga unsur-unsur yang ada dalam tanah dengan bantuan mikroorganisme dalam pupuk hayatibiobost mendekomposisi menjadi senyawa yang segera dapat langsung diserap oleh tanaman dalam hal benih tanaaman mentimun sehingga pemberian pupuk hayatibioboost mampu mempercepat proses perkecambahan.
Menurut Anonim (2017), bahwa pupuk hayati bioboost merupakan pupuk hayati cair yang mengandung mikroorganisme yang unggul dan bermanfaat untuk meningkatkan kesuburan tanah sebagai hasil proses biokimia tanah. Salah satu faktor yang mempengaruhi pertumbuhan dan perkembangan tanaman adalah penyiapan lahan (media) tanam dalam hal ini pemberian unsur hara berupa pupuk hayatibioboost. Hal tersebut memberikan penjelasan bahwa pupuk hayatibioboost merupakan pupuk yang unggul karena selain memperbaiki media tanam juga memacu perkecambahan benih.

Jumlah Daun

Pemberian pupuk hayati biobost pada dosis 40ml/liter air berpengaruh baik pada jumlah daun (Tabel 2), hal ini disebabkan karena pupuk bioboost mengandung unsur hara makro seperti Nitrogen, Fosfor dan Kalium yang dalam prose pertumbuhan tanaman pada fase vegetatif dalam hal ini jumlah daun sangat dibutuhkan dalam fungsinya daun sebagai media fotosintesis melalui zat hijau daun.

Untuk mendukung pertumbuhan tanaman secara keseluruhan tidak hanya membutuhkan satu unsur saja unsur tersebut seperti Fosfor yang merupakan bagian yang esensial dari berbagai gula posfat yang berperan dalam reaksi fotosintesis, respirasi dan metabolisme lainnya. Selanjutnya Kalium berperan sebagai aktivator dari berbagai enzim yang esensial dalam reaksi fotosintesis, sehingga dengan keberadaan pupuk bioboost sangat terbukti memacu pertumbuhan daun menjadi optimal. Plaster (2003), mengemukakan Nitrogen lebih diperlukan dalam menunjang pertumbuhan bagian vegetattif dibandingkan generatif dan penting bagi tanaman, sehingga pemberian Nitrogen dalam jumlah yang cukup menghasilkan tanaman yang vigor dan ukuran daun yang besar.

\section{Umur Berbunga}

Masa perkembangan tanaman terjadi ketika tanaman memasuki fase generatif yang diawali ketika tanaman umur tanaman mulai berbunga dengan munculnya bunga pada tanaman. Hasil penelitian menunjukkan bahwa pemberian pupuk organik cair bioboost $40 \mathrm{ml} /$ liter air memberikan pengaruh baik pada tanaman mentimun dengan umur berbunga lebih cepat. Hal ini diduga karena adanya suplai asimilat yang optimal dimana dalam pupuk cair bioboost yang mengandung Nitrogen sangat dibutuhkan dalam pembentukan asimilat sehingga dengan produksi asimilat yang tinggi pada bagian tanaman yang berwarna hijau maka ikut memacu masa perkembangan tanaman dalam hal ini umur berbunga.

Waktu berbunga tanaman yaitu saat tanaman memasuki masa perkembangan yang sangat berhubungan dengan hasil produksi yang maksimal yang ini sangat ditentukan oleh input yang diberikan pada tanaman dalam keadaan cukup dan seimbang dan mampu memenuhi kebutuhan tanaman (Nugroho, 2006). Sehubungan dengan hal tersebut maka pemebrian pupuk organik cair pupuk bioboost 40 $\mathrm{ml} /$ liter air dengan kandungan unsur hara makro esensial terbukti mampu memenuhi kebutuhan tanaman mentimun sehingga berpengaruh baikpada umur berbunga tanaman mentimun. 


\section{Jumlah Bunga}

Organ tanaman akan kokoh dan kuat serta dapat bertahan ketika suplai hara, mineral dan air dari dalam tanah keseluruh organ tanaman tersedia dan dalam keadaan yang cukup mampu memenuhi kebutuhan tanaman sehingga akan berjalan secara meksimal. Hasil penelitian pada (Tabel 4) pemberian pupuk bioboost $40 \mathrm{ml} /$ liter air memberikan pengaruh baik pada jumlah bunga tanaman mentimun karena dalam pupuk organik cair bioboost juga banyak mengandung bakteri pengurai yang mempercepat proses perombakan makanan menjadi bentuk tersedia untuk suplai dan ditranlokasikan keorgan bunga.

Kandungan dan manfaat pupuk organik cair bioboost terdapat zat pengatur tumbuh, mengandung anti jamur dan dapat menghilangkan jamur pada organ batang dan akar. Mengacu pada kandungan dan manfaat pupuk bioboost dengan adanya zat pengatur tumbuh dan mampu menghilangkan serangan jamur maka menjadi penyebab sehingga bunga yang terbentuk pada tanaman mentimun mmapu bertahan dan tidak gugur sehingga jumlah bunganya berpengaruh baik.

Jumlah Buah

Banyaknya jumlah bunga akan berpengaruh pada jumlah buah yang terbentuk yang tentunya diawali dengan optimalnya fase pertumbuhan vegetaif sehingga hasil produksi jumlah buah juga optimal. Pemberiaan pupuk bioboost $40 \mathrm{ml} /$ liter air berpengaruh baikpada jumlah buah mentimun (Tabel 5). Tanaman yang tumbuh kokoh dan ketersediaan makanan mencukupi merupakan faktor yang sangat menentukan pada hasil akhir dari tanaman dalam hal ini jumlah buah yang dihasilkan tanaman mentimun. Sehubungan dengan pendapat (Jumin HB, 2002), peningkatan hasil tanaman mempunyai hubungan yang sangat erat dengan peningkatan pertumbuhan relatif hasil bersih asimilasi sehingga produksi optimum hasil tanaman akan mencapai pada kondisi yang maksimum jika suplai asimilat optimal.

Pupuk bioboost mengandung unsur Nitrogen, Posfat, dan Kalium, asam amino, bakteri pengurai dan sifat pupuk ini sebagai puk organik yang bersumber dariabahan alami sehingga tidak menyebabkan kerusakan pada tanaman maupun lingkungan menjadi suatu penyebab utama sehingga produksi jumlah buah mentimun memberikan hasil yang signifikan.

\section{Panjang Buah}

Buah yang baik pada tanaman mentimun salah satunya dicirikan dengan panjang buah yang dihasilkan dan merupakan mempunyai nilai ekonomi yang diharapkan akan memberikan nilai pendapatan yang akan digunakan kembali dalam suatu usahatani.

Penelitian mentimun melalui pemberian pupuk bioboost $40 \mathrm{ml}$ / liter air memberikan pengaruh baik pada panjang buah tanaman mentimun, hal ini disebabkan adanya suplai hara ke fase pembentukan buah optimal sehingga diikuti oleh panjang buah mentimun yang berpengaruh baik. Menurut Gardner F (2009), berpendapat jika suplai asimilat optimal maka pada fase perkembangan suatu tanaman maka produksinya akan meningkat dan sangat ditentukan oleh kemampuan tanaman dalam mensuplai dan mengabsorbsi unsur hara, mineral dan air dalam masa produksi.

\section{Berat Buah}

Pada penelitian ini parameter berat buah pemberian pupuk organik cair bioboost $40 \mathrm{ml} /$ liter air (Tabel 7) memberikan pengaruh baik, ini menunjukkan bahwa berat buah juga dipengaruhi oleh keadaan hara yang tersedia dalam media tanam karena penggunaan pupuk hayati bioboost yang mengandung mikroorganisme yang dapat meningkatkan kesuburan tanah.

Setyamidjaja (1996), mengemukakan bahwa unsur hara merupakan unsur-unsur kimia tertentu yang dibutuhkan oleh tanaman untuk pertumbuhan dan perkembangannya yang normal, tidak tersedianya unsur hara bagi tanaman akan menyebabkan pertumbuhan terganggu dan akan menurunkan hasil produksi. Berdasarkan hal tersebut terbukti bahwa dengan penggunaan pupuk biobosst memperbaiki hasil produksi yang salah satu manfaatnya meningkatkan hasil panen.

\section{KESIMPULAN}

Hasil penelitian yang telah dilaksanakan maka kesimpulannya sebagai berikut :

1. Interaksi interval waktu pemberian dengan dosis pupuk hayati bioboost ( $\mathrm{Z}$ x F) tidak memberikan pengaruh pada pertumbuhan dan produksi tanaman mentimun pada semua parameter

2. Interval waktu pemberian pupuk hayati bioboost (W) tidak memberikan pengaruh baik terhadap pertumbuhan dan produksi tanaman mentimun pada semua parameter.

3. Pemberian pupuk hayati bioboost dosis $40 \mathrm{ml} /$ liter air (F2) berpengaruh baik pada parameter umur berkecambah, jumlah daun, umur berbunga, jumlah bunga, jumlah buah, panjang buah dan berat buah tanaman mentimun.

\section{Saran}

Tanaman mentimun akan baik pertumbuhan dan produksinya dengan penggunaan pupuk hayati bioboost dosis $40 \mathrm{ml} /$ liter air.

\section{DAFTAR PUSTAKA}

Abdurahman, 2008 dalam Neichita Ayu Ariani, 2015.Pengaruh Pemberian Pupuk Hayati terhadap pertumbuhan dan hasil tanaman kacang tanah (Arachis hypogea). Universitas Airlangga. Surabaya.

Anonim, 2017.Pupuk Cair Bioboost. Penerbit Sinar Tani, Jakarta.

Anonim. 2017. Klasifikasi dan Morfologi dari Tanaman Timun Secara Tepat.https://www.sedulurtani.com/klasifikasi -dan-morfologi-dari-tanaman-timun-secaratepat/. Diakses pada Tanggal 1 Maret 2019.Ari Maryanto, SST. 2017. Pembumbunan dan Penyiangan Tanaman Jagung. BPP Sentolo.Sentolo. 
Enice, Dahlia Nurdin, Harli A. Karim / Tingkatan Keberhasilan Penggunaan Pupuk Hayati Biosboost ...

BPS. 2018. Data Hortikultura. https://www.bps.go.id/. Diakses pada Tanggal 18 Maret 2019.

Cahyono, 2003. dalamPutri Wulansari, Puji Rahayu Mashfufatul Zulaikha.Universitas Tidar. 2017Budidaya Tanaman Mentimun (Cucumis sativa L) pada Media Arang Sekam

Direktorat Perbenihan Hortikultura. 2011. Pedoman Penyusunan Deskripsi Varietas Hortikultura. Direktorat Perbenihan Hortikultura. Ditjend. Hortikultura. KementanRI. 218 hal.

Djiwosaputro (1990) dalam Hidayat, dkk. (2013). Pengantar FisiologiTumbuhan. Gramedia, Jakarta.

(Driyunita dan Litha Pasapan.2015. Pengaruh Pemberian Berbagai Konsentrasi Pupuk Cair Bioboost terhadap Pertumbuhan Tanaman Srawberry (Fragaria sp) Universitas Kristen Indonesia.Toraja.

Fredi Kurniawan. 2016. Klasifikasi dan Morfologi Tanaman Mentimun http://fredikurniawan.com/klasifikasi-danmorfologi-tanaman-mentimun/

Gardner F, 2009. Fisiologi Tanaman Budidaya. Penerbit Universitas Indonesia (UI- Pers), Jakarta.

Hamdani, J. S., dan T. Simarmata. (2003) dalam Hasyiatun Y. dkk (2015). Pertumbuhandan hasil jahe (Zingiber officinale Rose.) cultivar gajah yang dipanen muda pada berbagaijenis dan dosis pupuk organik dan anorganik.Jurnal Kultivasi. 2(2): 26-32

Imdad dan Nawangsih, 2001.dalamMomi, 2019.Pengaruh Pemberian Pupuk Nitrogen dengan Zat perangsang Tumbuh Giberelin (GA) terhadap Pertumbuhan dan hasil Tanaman Mentimun. Universitas muhammadiyah Purwokerto.Purwokerto.

Indrakusuma. (2000) dalamHasyiatun Y. dkk (2015). Proposal Pupuk Organik CairSupra Alam Lestari. PT Suya Pratama Alam.Yogyakarta.

Jumin HB, 2009. Ekologi Tanaman Suatu Pendekatan Fisiologis. Penerbit Rajawali Pers, Jakarta

Mustaman, M., \& Fatman, M. (2018). Pengaruh Pemberian Berbagai Jenis Pupuk Kandang Dan Media Tanam Yang Berbeda Terhadap Pertumbuhan Dan Produksi Tanaman Mentimun (Cucumis sativus L.). AGROVITAL: Jurnal Ilmu Pertanian, 2(2), 8892 .

Manalu, 2013.dalam Momi, 2019. Pengaruh Pemberian Pupuk Nitrogen dengan Zat perangsang
Tumbuh Giberelin (GA) terhadap Pertumbuhan dan hasil Tanaman Mentimun. Universitas muhammadiyah Purwokerto. Purwokerto.

Nugroho H, 2006. Struktur dan Perkembangan Tumbuhan. Penerbit Penebar Swadaya, Jakarta.

Plaster E J, 2003. Soil Science and Management. Delmar Learning Inc, United States.

Rizqiani, 2007.dalam Neichita Ayu Ariani, 2015. Pengaruh Pemberian Pupuk Hayati terhadap pertumbuhan dan hasil tanaman kacang tanah (Arachis hypogea).Universitas Airlangga. Surabaya.

Rukmana, R.1994 dalam Andrie KL, Marisi Napitupulu, dan Noor Jannah (2015).Budiday Mentimun.Kanisius.Yogyakarta.

Septiyaning, Indah. 2011. Kemarau Hasil Panen Mentimun Menyusut. http://www.solopos.com/2 $011 / \mathrm{k}$ a $\mathrm{r}$ a $\mathrm{n}$ g a $\mathrm{n}$ y a r / k e ma r a u -h a s i l - p a n e n mentimun-menyusut-116147. Solo Pos. Solo. Diakses pada tanggal : 9 Maret 2019.

Setyamidjaja D, 1996. Pupuk dam Pemupukan Penerbit Pustaka Ilmu, Jakarta.

Simanungkalit, 2006.dalam Neichita Ayu Ariani, 2015. Pengaruh Pemberian Pupuk Hayati terhadap pertumbuhan dan hasil tanaman kacang tanah (Arachis hypogea). Universitas Airlangga. Surabaya.

Sumpena, U.2001 dalam Hasyiatun Y. dkk 2015.Pengaruh Pemberian Pupuk Organik Cair dan Dosis Pupuk NPK (15:15:15) terhadap Pertumbuhan dan Produksi Tanaman Mentimun (Cucumis sativus L.).J. Agrotek Tropika. ISSN 2337-4993Vol. 3, No. 1: 30 - 35, Januari 2015 Fakultas Pertanian Universitas Lampung.

Sutejo,M.M. dan A.G. Kartasapoetra. 1995. Pengaruh Pemberian Pupuk Organik Cair dan Dosis Pupuk NPK (15:15:15) terhadap Pertumbuhan dan Produksi Tanaman Mentimun (Cucumis sativus L.).J. Agrotek Tropika. ISSN 23374993Vol. 3, No. 1: 30 - 35, Januari 2015 Fakultas Pertanian Universitas Lampung.

Soetejo dan Kartasapoetra, 1991.dalam Hasyiatun Y. Kurniawati, Agus Karyanto \& Rugayah. 2015. Pengaruh Pemberian Pupuk Organik Cair dan Dosis Pupuk NPK (15:15:15) terhadap Pertumbuhan dan Produksi Tanaman Mentimun (Cucumis sativus L.).J. Agrotek Tropika. ISSN 2337-4993Vol. 3, No. 1: 30 - 35, Januari 2015 Fakultas Pertanian Universitas Lampung. 
Enice, Dahlia Nurdin, Harli A. Karim / Tingkatan Keberhasilan Penggunaan Pupuk Hayati Biosboost ...

Simarmata, T. 2005 dalam Hasyiatun Y. dkk

2015.Pengaruh Pemberian Pupuk Organik Cair dan Dosis Pupuk NPK (15:15:15) terhadap Pertumbuhan dan Produksi Tanaman Mentimun (Cucumis sativus L.).J. Agrotek Tropika. ISSN 2337-4993Vol. 3, No. 1: 30 - 35, Januari 2015 Fakultas Pertanian Universitas Lampung.

Pranata. 2010. dalam Neichita Ayu Ariani. 2015. Pengaruh Pemberian Pupuk Hayati terhadap pertumbuhan dan hasil tanaman kacang tanah (Arachis hypogea). Universitas Airlangga. Surabaya. 